\title{
Experience Outside of Clinical Trial with Cyclin Inhibitors
}

\author{
Losada B* \\ Department of Medical Oncologist, Fuenlabrada University Hospital, Spain
}

Submission: September 05, 2018; Published: October 24, 2018

"Corresponding author: Losada B, Department of Medical Oncologist, Fuenlabrada university Hospital, Madrid, Spain, Tel: +34916006000; Email: beamenta@hotmail.com

Keywords: Breast cancer; Cyclin inhibitor; Toxicity; Tolerance and Hepatic

\section{Introduction}

Luminal metastatic breast cancer has experienced a great advance thanks to the emergence of cyclin inhibitors, being a new line of treatment very well tolerated and that manages to prolong the overall survival in> 24 months based on the studies PALOMA-2, PALOMA-3 AND MONALEESA [1-3]. The aim of our study is to reflect the clinical characteristics of patients treated with cyclin inhibitor in the last months since its approval as well as the tolerance and toxicity profile.

\section{Material and Methods}

Retrospective study of 8 patients diagnosed in the University Hospital of Fuenlabrada in treatment with cyclin inhibitor in the last 4 months.

\section{Results}

$50 \%$ of patients are $<65$ years old ( 3 premenopausal, on treatment with gnRH analog in $2 / 3$ and $1 / 3$ oophorectomy), with an ECOG $0-1$ in $100 \%$. $75 \%$ have expression of both estrogen and progesterone receptors, with $25 \%$ presenting only estrogenpositive receptors. $75 \%(6 / 8)$ was initially diagnosed as a locally advanced tumor and only $25 \%$ started as a metastatic disease. The disease-free interval was less than 2 years in $50 \%$ (4/8) of the patients. $25 \%$ present 3 or more metastatic locations, while the remaining $75 \%$ present between $1-2$ locations. $25 \%$ have exclusive bone disease while $37.5 \%$ have visceral involvement. All patients except those with bone involvement have measurable disease. Regarding the treatments received, $25 \%$ had received fulvestrant and only one of them $(12.5 \%)$ received chemotherapy for metastatic disease. $62.5 \%$ receive cyclins as the first line of metastatic disease while $25 \%$ receive it in the 5th line and the remaining $12.5 \%$ in the $3 \mathrm{rd}$ line. $50 \%$ receivec in combination with cyclins, while $37.5 \%$ combine it with letrozole, $12.5 \%$ with exemestane. $75 \%$ receive palbociclib while the other $25 \%$ ribociclib.
All patients currently continue to have cyclin inhibitors, except one $(12.5 \%)$ that progresses to the pleural level at 3 months and is being treated with paclitaxel. The most frequently reported toxicity is in the form of neutropenia (grade 2 in $37.5 \%$ ) that occurs in the first or second cycle and needs a delay of 1 week of treatment. Only in $1 / 8(12.5 \%)$ dose adjustment to $100 \mathrm{mg}$ daily of palbociclib is needed. No patient presented hepatic or cardiac toxicity

\section{Conclusions}

a) The treatment with cyclin inhibitors is safe and with a manageable profile of side effects.

b) The profile of patients being treated outside the clinical trial is both pre and postmenopausal (50\%> 65 years, ECOG 0-1 and with several metastatic locations.

c) The most frequent toxicity is in the form of grade 2 neutropenia that after a dose delay of one week is recovered and usually does not need dose reduction [1-3].

\section{References}

1. Kaiser T, Köhler M, Wieseler B (2018) Reporting of HRQOL results from the PALOMA-2 trial: unfounded conclusions due to highly biased analyses. Ann Oncol 29(8): 1877.

2. Cristofanilli M, Turner NC, Bondarenko I, Ro J, Im SA, et al. (2016) Fulvestrant plus palbociclib versus fulvestrant plus placebo for treatment of hormone-receptor-positive, HER2-negative metastatic breast cancer that progressed on previous endocrine therapy (PALOMA-3): final analysis of the multicentre, double-blind, phase 3 randomised controlled trial. Lancet Oncol 17(4): 425-439.

3. Slamon DJ, Neven P, Chia S, Fasching PA, De Laurentiis M, et al. (2018) Phase III Randomized Study of Ribociclib and Fulvestrant in Hormone Receptor-Positive, Human Epidermal Growth Factor Receptor 2-Negative Advanced Breast Cancer: MONALEESA-3. J Clin Oncol 36(24): 2465-2472. 
This work is licensed under Creative Commons Attribution 4.0 License

\section{Your next submission with Juniper Publishers} will reach you the below assets

- Quality Editorial service

- Swift Peer Review

- Reprints availability

- E-prints Service

- Manuscript Podcast for convenient understanding

- Global attainment for your research

- Manuscript accessibility in different formats ( Pdf, E-pub, Full Text, Audio)

- Unceasing customer service

Track the below URL for one-step submission https://juniperpublishers.com/online-submission.php 